\title{
Glass Formation in Ni-Zr-(Al) Alloy Systems
}

\author{
Lanping Huang and Song Li \\ State Key Laboratory for Powder Metallurgy, Central South University, Changsha 410083, China \\ Correspondence should be addressed to Song Li; 1s2011sl@csu.edu.cn
}

Received 12 April 2013; Accepted 3 August 2013

Academic Editor: Ram Katiyar

Copyright (C) 2013 L. Huang and S. Li. This is an open access article distributed under the Creative Commons Attribution License, which permits unrestricted use, distribution, and reproduction in any medium, provided the original work is properly cited.

\begin{abstract}
Structural and thermal properties of binary $\mathrm{Ni}_{100-x} \mathrm{Zr}_{x}(30<x<75)$ alloys obtained by melt spinning and copper mold casting methods were investigated. The fully amorphous samples in a bulk form cannot be obtained in the binary Ni-Zr alloys over a wide composition range, though they have $T_{g} / T_{l}$ and $\gamma$ values close to or even higher than those of the binary Cu-Zr bulk metallic glasses (BMGs). The low thermal stability of the supercooled liquid against crystallization and the formation of the equilibrium crystalline phases with a high growth rate are responsible for their low glass-forming abilities (GFAs). Relatively low thermal conductivities of Ni-based alloys are also considered to be another factor to limit their GFAs. The GFA of the binary $\mathrm{Ni}_{65.5} \mathrm{Zr}_{34.5}$ alloy alloyed with $4 \%$ or $5 \% \mathrm{Al}$ was enhanced, and a fully glassy rod with a diameter of $0.5 \mathrm{~mm}$ was formed.
\end{abstract}

\section{Introduction}

Bulk metallic glasses (BMGs) have attracted much attention due to their excellent properties compared with their crystalline counterparts and potential applications as structural materials [1-3]. A variety of BMGs with high glass-forming ability (GFA) based on multiple components have been developed over the past two decades or so [4-10]. Among these BMGs, ordinary Ni-based BMGs are very attractive for engineering applications because of their ultrahigh strength and relatively low cost. Ni-based amorphous alloys with diameters of more than $1 \mathrm{~mm}$ have also been produced since 1999 [11-16]. These Ni-based BMGs belong mainly to LTM-ETM (LTM-late transition metals, ETM-early transition metals) group of alloys. Now, their critical value of thickness is up to $15 \mathrm{~mm}$, but metalloids included in some alloy systems have tampered their manufacturability. So, it is necessary to develop new Ni-based BMGs including only common metallic elements. Developing new Ni-based BMGs is expected to expand engineering applications and is important for understanding the long-standing issues of glass formation mechanism.

Various empirical methods have been proposed to guide the discovery of BMGs with higher GFA $[1,10,17]$. The $T_{\mathrm{rg}}$ criterion widely used as a long-standing guideline has predicted that deep eutectics are preferable for glass formation upon cooling a liquid, so the compositions near the eutectics have been chosen preferentially to obtain BMG in either simple binary or multiple component systems. It is generally known that binary alloys must have a very high critical cooling rate required to avoid crystallization upon cooling from liquid state because of the simplicity of their chemical compositions. However, some binary alloys such as $\mathrm{Ni}-\mathrm{Nb}, \mathrm{Cu}-\mathrm{Zr}$, and $\mathrm{Cu}-\mathrm{Hf}$ can be bulk glass formers [18-22], though nanocrystalline phases are included. These binary metallic glasses provided an important guidance to search for ordinary multicomponent BMGs with extremely good GFA [14-17]. As well as $\mathrm{Ni}-\mathrm{Nb}$ and $\mathrm{Cu}-\mathrm{Zr}$ binary alloy systems, the Ni-Zr one has been also known to be a system in which the amorphous phase can be formed over wide composition ranges by rapid quenching techniques. However, no systematic studies were preformed on the mold casting of this system. In the current work, the alloys with near eutectic composition $\left(\mathrm{Ni}_{64} \mathrm{Zr}_{36}\right)$ have been chosen by analogy with the similar $\mathrm{Cu}$-Zr bulk glassy alloys. The GFA and thermal properties of the $\mathrm{Ni}_{100-x} \mathrm{Zr}_{x}(30<x<75)$ alloys have been investigated. Besides, the influence of $\mathrm{Al}$ addition on the GFA and thermal stability of the binary Ni-Zr alloys was studied.

\section{Experimental}

The alloy ingots studied in this work were prepared by arc melting mixtures of $\mathrm{Ni}, \mathrm{Zr}$, and $\mathrm{Al}$ with purities of $99.97 \mathrm{wt} . \%$, 


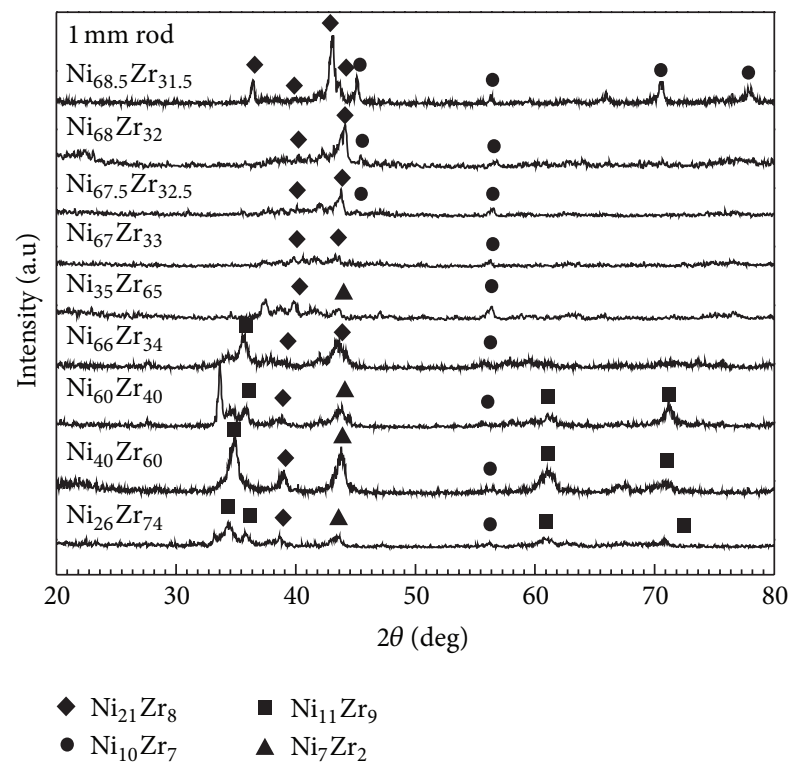

FIGURE 1: XRD patterns of the as-cast $\mathrm{Ni}_{100-x} \mathrm{Zr}_{x}(30<x<75)$ alloy rods with a diameter of $1 \mathrm{~mm}$.

99.9 wt.\%, and 99.99 wt.\%, respectively, in a Ti-gettered high purity argon atmosphere. The ingots were remelted at least three times to ensure the homogeneity of the samples. The alloyed ingots were then remelted in an evacuated state in a quartz tube using an induction heating coil followed by injection through a nozzle with a diameter of 0.5 or $1 \mathrm{~mm}$. The ribbon samples were fabricated using a singleroller melt spinning apparatus. The structures of the as-cast samples were studied using X-ray diffraction (XRD) with $\mathrm{Cu}-\mathrm{K} \alpha$ radiation. The thermal properties were examined by a differential scanning calorimeter (DSC) at a heating rate of $0.67 \mathrm{~K} / \mathrm{s}$ and differential thermal analysis (DTA) at a heating rate of $0.33 \mathrm{~K} / \mathrm{s}$.

\section{Result and Discussion}

In the $\mathrm{Ni}-\mathrm{Zr}$ alloy system, the compositions that we have primarily focused on are close to the eutectic point $\mathrm{Ni}_{64} \mathrm{Zr}_{36}$ by analogy with $\mathrm{Cu}-\mathrm{Zr}$ bulk glassy alloys. In addition, other compositions like $\mathrm{Ni}_{40} \mathrm{Zr}_{60}, \mathrm{Ni}_{35} \mathrm{Zr}_{65}$, and $\mathrm{Ni}_{26} \mathrm{Zr}_{74}$ were also investigated. Figure 1 shows XRD patterns of the as-cast $\mathrm{Ni}_{100-x} \mathrm{Zr}_{x}(30<x<75)$ alloy rods with a diameter of $1 \mathrm{~mm}$. It is seen that all these binary alloy specimens exhibit crystalline Bragg peaks, corresponding to different crystalline phases such as $\mathrm{Ni}_{21} \mathrm{Zr}_{8}, \mathrm{Ni}_{10} \mathrm{Zr}_{7}, \mathrm{Ni}_{11} \mathrm{Zr}_{9}$, and $\mathrm{Ni}_{7} \mathrm{Zr}_{2}$, indicating that they cannot have a fully amorphous structure in a bulk form. The equilibrium $\mathrm{Ni}_{10} \mathrm{Zr}_{7}$ compound, which is typical in some Ni-based alloys [23], and eutectic-type $\mathrm{Ni}_{21} \mathrm{Zr}_{8}$ phase can be observed in those alloys near eutectic compositions. If the nucleation and growth of these intermetallic compounds can be restrained, a fully amorphous structure will be obtained in $\mathrm{Ni}-\mathrm{Zr}$ alloy system. Figure 2 presents XRD patterns of the $\mathrm{Ni}_{67} \mathrm{Zr}_{33}$ melt spun ribbons prepared at different spinning velocities. At the spinning velocity of $4000 \mathrm{rpm}$, corresponding to the thickness of about

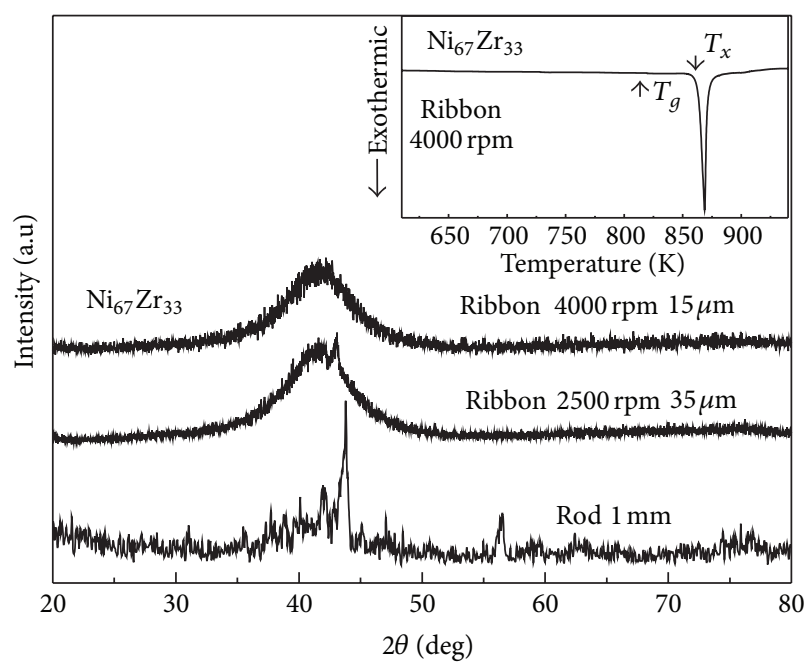

FIGURE 2: XRD patterns of the as-cast $\mathrm{Ni}_{67} \mathrm{Zr}_{33}$ melt spun ribbons at different spinning velocities. The inset is DSC curve of $\mathrm{Ni}_{67} \mathrm{Zr}_{33}$ melt spun ribbon at $4000 \mathrm{rpm}$.

TABLE 1: Critical thickness $d_{C}$, reduced glass transition temperature $T_{\text {rg }}$, supercooled liquid region width $\Delta T$, and $\gamma$ of typical binary BMGs and $\mathrm{Ni}_{67} \mathrm{Zr}_{33}$ metallic glasses.

\begin{tabular}{lcccc}
\hline $\begin{array}{l}\text { Alloy composition } \\
\text { (at.\%) }\end{array}$ & $d_{C}(\mathrm{~mm})$ & $\Delta T(\mathrm{~K})$ & $T_{\text {rg }}$ & $\gamma$ \\
\hline $\mathrm{Ni}_{67} \mathrm{Zr}_{33}$ & 0.03 & 39 & 0.60 & 0.39 \\
$\mathrm{Cu}_{50} \mathrm{Zr}_{50}$ & 2 & 58 & 0.555 & 0.387 \\
$\mathrm{Cu}_{64} \mathrm{Zr}_{36}$ & 2 & 48 & 0.64 & 0.41 \\
$\mathrm{Ni}_{62} \mathrm{Nb}_{38}$ & 2 & 40 & 0.60 & 0.392 \\
\hline
\end{tabular}

$15 \mu \mathrm{m}$, the as-cast ribbon exhibits typical broad diffraction maxima of amorphous structure, and no obvious crystalline peaks can be observed with the XRD resolution limits. When the spinning velocity decreases from $4000 \mathrm{rpm}$ to $2500 \mathrm{rpm}$, corresponding to the thickness of about $35 \mu \mathrm{m}$, some small crystalline peaks appear in the XRD pattern, indicating the formation of nanocrystalline phases in glassy matrix. This shows that the formation of these crystalline phases is very sensitive to the cooling rate. The inset is the DSC curve of the $\mathrm{Ni}_{67} \mathrm{Zr}_{33}$ ribbon prepared at $4000 \mathrm{rpm}$. It is noted that a distinct endothermic characteristic of the glass transition followed by a sharp crystallization peak is clearly exhibited. The values of the glass transition temperature $T_{g}$ and onset temperature of crystallization $T_{x}$ are measured to be $835 \mathrm{~K}$ and $860 \mathrm{~K}$, respectively. Figure 3 presents DTA curve of the as-cast $\mathrm{Ni}_{100-x} \mathrm{Zr}_{x}(65.5<x<68)$ alloy rods. With the addition of $\mathrm{Ni}$, the onset melting temperature $T_{m}$ of $\mathrm{Ni}_{100-x} \mathrm{Zr}_{x}$ alloys also increases, but not the values of the liquid temperature $T_{l}$ ( $T_{l}$ is somewhat overestimated as it is obtained on heating at $0.33 \mathrm{~K} / \mathrm{s}$ ).

Table 1 lists the parameters denoting GFA of typical binary BMGs and $\mathrm{Ni}_{67} \mathrm{Zr}_{33}$ metallic glasses. It is seen that the $T_{g} / T_{l}$ and $\gamma$ values of binary $\mathrm{Ni}_{67} \mathrm{Zr}_{33}$ are close or even higher than those of $\mathrm{Cu}-\mathrm{Zr}$ and $\mathrm{Ni}-\mathrm{Nb}$ BMGs, though no bulk glassy alloys were obtained in the studied binary $\mathrm{Ni}-\mathrm{Zr}$ alloys. 


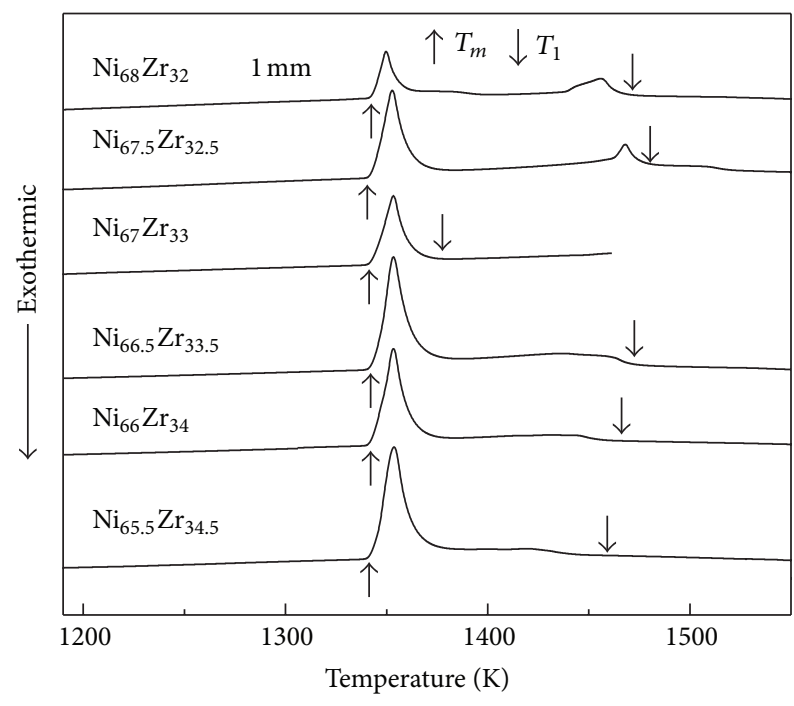

Figure 3: DTA curves of the as-cast $\mathrm{Ni}_{100-x} \mathrm{Zr}_{x}(65.5<x<68)$ alloy rods with a diameter of $1 \mathrm{~mm}$.

The reasons for the lower GFA of binary Ni-Zr alloys might be explained as follows. Recently, thermodynamic simulations of the $\mathrm{Ni}-\mathrm{Zr}$ and $\mathrm{Cu}-\mathrm{Zr}$ alloy systems have been assessed in the relation with short range ordering in the liquid [24]. The critical cooling rates in the $\mathrm{Cu}-\mathrm{Zr}$ alloys are predicted to be smaller than those in Ni-Zr alloys, suggesting that $\mathrm{Cu}-\mathrm{Zr}$ alloys have higher GFA than Ni-Zr alloys. While the driving force for crystallization in the Ni-Zr alloys may be much higher than those in the $\mathrm{Cu}-\mathrm{Zr}$ and $\mathrm{Ni}-\mathrm{Nb}$ alloys, this means that crystalline phases in $\mathrm{Ni}-\mathrm{Zr}$ alloys can nucleate and grow up more easily than those in $\mathrm{Cu}-\mathrm{Zr}$ and $\mathrm{Ni}-\mathrm{Nb}$ alloys in an undercooled alloy melt. The difference in the atomic configuration of $\mathrm{Ni}-\mathrm{Zr}$ and $\mathrm{Cu}-\mathrm{Zr}$ metallic glasses also plays an important role in their GFAs. An icosahedron-like structure in $\mathrm{Cu}-\mathrm{Zr}$ BMGs makes glassy phase more stable, but $\mathrm{Ni}-\mathrm{Zr}$ metallic glasses do not have the same structure [25]. Otherwise, the thermal conductivity of the molten alloy, indicating its ability to transfer heat upon cooling, also affects the GFA of the alloy. It has been reported that Ni-based alloys have much lower thermal conductivity than $\mathrm{Cu}$-based alloys [26].

To improve the GFA of the binary Ni-Zr alloys, Al element as the third component was added in binary $\mathrm{Ni}-\mathrm{Zr}$ alloy system. Since the atomic radius of $\mathrm{Zr}$ is $18 \%$ larger than that of $\mathrm{Ni}$, it is predicted that maximum packing density in the undercooled liquid is obtained at around 35 at.\% $\mathrm{Zr}$ in binary Ni-Zr alloys. So, the composition $\mathrm{Ni}_{65.5} \mathrm{Zr}_{34.5}$ has been selected as the starting point. In contrast, the off-eutectic composition $\mathrm{Ni}_{67} \mathrm{Zr}_{33}$ has also been selected. Figure 4 shows XRD patterns of the as-cast $\left(\mathrm{Ni}_{65.5} \mathrm{Zr}_{34.5}\right)_{100-x} \mathrm{Al}_{x}(x \leq$ 8) alloys. All the $1 \mathrm{~mm}$-diameter rods exhibit an apparent evidence of crystalline Bragg peaks, corresponding to different crystalline phases such as $\mathrm{Ni}_{21} \mathrm{Zr}_{8}, \mathrm{Ni}_{10} \mathrm{Zr}_{7}, \mathrm{Ni}_{2} \mathrm{Zr}$, and $\mathrm{AlNi}_{2} \mathrm{Zr}$, while the $0.5 \mathrm{~mm}\left(\mathrm{Ni}_{65.5} \mathrm{Zr}_{34.5}\right)_{96} \mathrm{Al}_{4}$ rod has a fully amorphous structure. Figure 5 presents DSC curves of the as-cast $\left(\mathrm{Ni}_{65.5} \mathrm{Zr}_{34.5}\right)_{100-x} \mathrm{Al}_{x}(x \leq 8)$ alloys at a heating

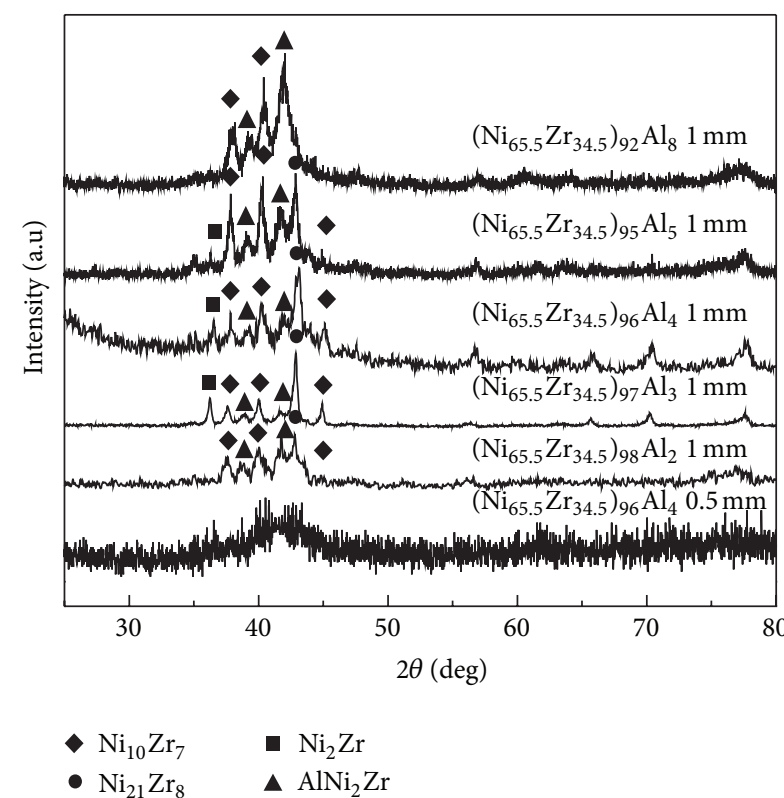

FIGURE 4: XRD patterns of the as-cast $\left(\mathrm{Ni}_{65.5} \mathrm{Zr}_{34.5}\right)_{100-x} \mathrm{Al}_{x}(x \leq 8)$ alloys with the diameters of 0.5 and $1 \mathrm{~mm}$.

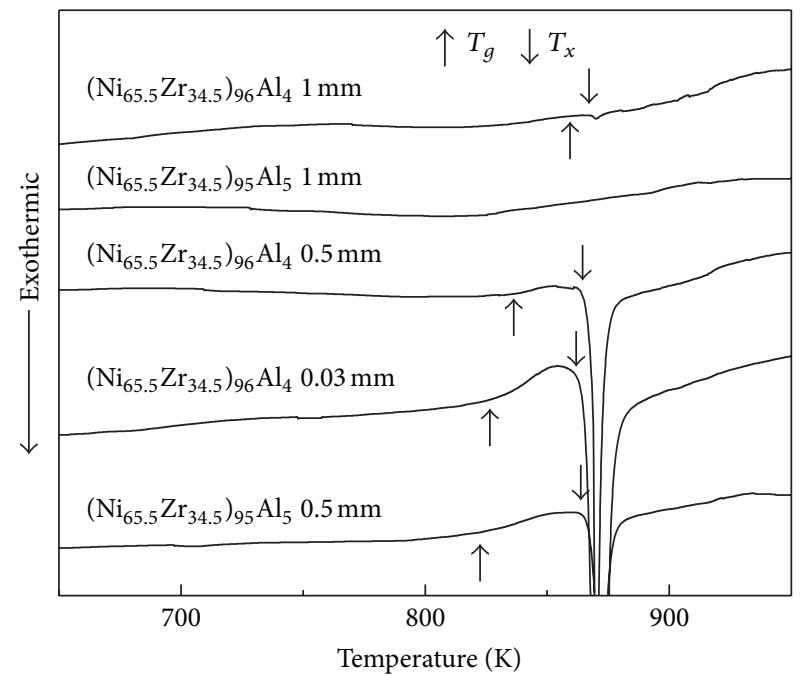

FIgURE 5: DSC curves of the as-cast $\left(\mathrm{Ni}_{65.5} \mathrm{Zr}_{34.5}\right)_{100-x} \mathrm{Al}_{x}(x \leq 8)$ alloys at a heating rate of $40 \mathrm{~K} / \mathrm{min}$.

rate of $40 \mathrm{~K} / \mathrm{min}$. It is found that only $\left(\mathrm{Ni}_{65.5} \mathrm{Zr}_{34.5}\right)_{96} \mathrm{Al}_{4}$ and $\left(\mathrm{Ni}_{65.5} \mathrm{Zr}_{34.5}\right)_{95} \mathrm{Al}_{5}$ alloys exhibit an obvious endothermic characteristic of the glass transition followed by a characteristic exothermic heat event indicating the successive stepwise transformations from supercooled liquid state to crystalline phases. The DTA curves of the as-cast $\left(\mathrm{Ni}_{65.5} \mathrm{Zr}_{34.5}\right)_{100-x} \mathrm{Al}_{x}$ $(x \leq 8)$ alloys at a heating rate of $10 \mathrm{~K} / \mathrm{min}$ are shown in Figure 6 . With the addition of $\mathrm{Al}$ in these alloys, the values of $T_{m}$ and $T_{l}$ will decrease. Figure 7 presents a DSC curve of the as-cast $\left(\mathrm{Ni}_{65.5} \mathrm{Zr}_{34.5}\right)_{96} \mathrm{Al}_{4}$ alloy rod with a diameter of $0.5 \mathrm{~mm}$ scanned at a heating rate of $40 \mathrm{~K} / \mathrm{min}$, and the inset is a DTA curve of this alloy at a heating rate of $20 \mathrm{~K} / \mathrm{min}$. The ternary 


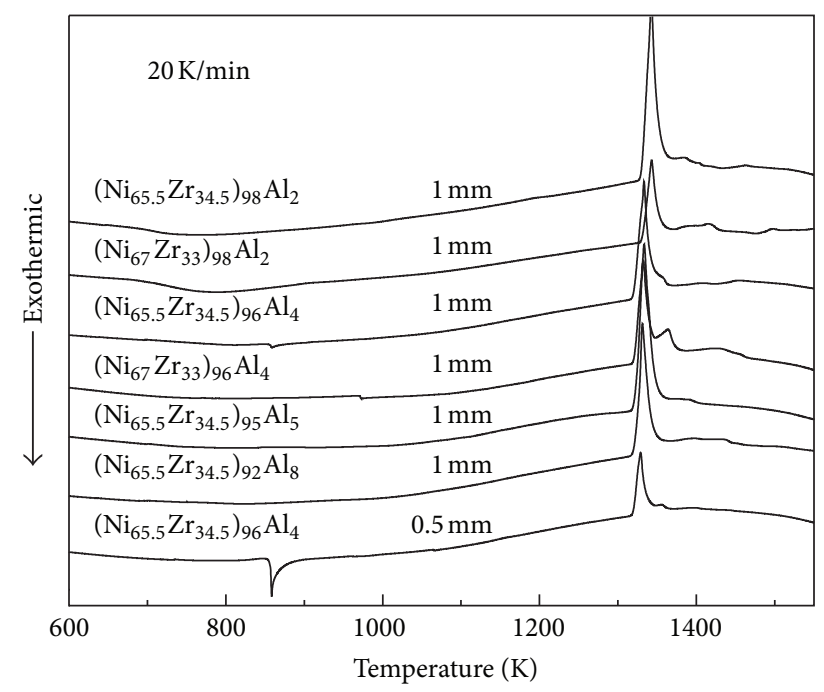

Figure 6: DTA curves of the as-cast $\left(\mathrm{Ni}_{65.5} \mathrm{Zr}_{34.5}\right)_{100-x} \mathrm{Al}_{x}$ and $\left(\mathrm{Ni}_{67} \mathrm{Zr}_{33}\right)_{100-x} \mathrm{Al}_{x}(x \leq 10)$ alloys at a heating rate of $20 \mathrm{~K} / \mathrm{min}$.

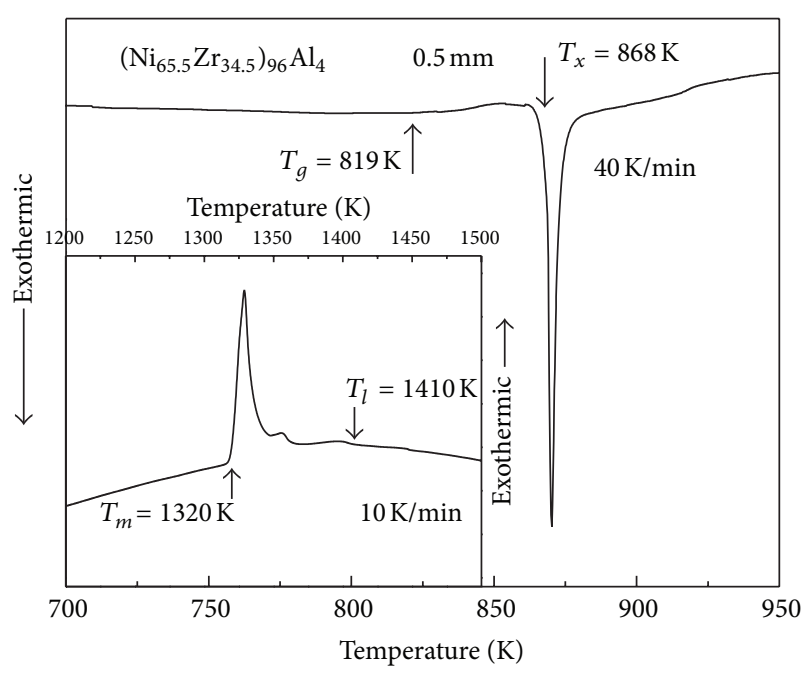

FIGURE 7: DSC and DTA curves of the as-cast $\left(\mathrm{Ni}_{65.5} \mathrm{Zr}_{34.5}\right)_{96} \mathrm{Al}_{4}$ with a diameter of $0.5 \mathrm{~mm}$.

$\left(\mathrm{Ni}_{65.5} \mathrm{Zr}_{34.5}\right)_{96} \mathrm{Al}_{4}$ alloy shows a clear glass transition at $T_{g}=$ $819 \mathrm{~K}$, followed by crystallization with $T_{x}=868 \mathrm{~K}$, giving a supercooled liquid region $\Delta T=T_{x}-T_{g}=49 \mathrm{~K}$, and the values of $T_{m}$ and $T_{l}$ are determined to be $1320 \mathrm{~K}$ and $1410 \mathrm{~K}$, respectively. The values of $T_{\mathrm{rg}}$ and $\gamma$ of $\left(\mathrm{Ni}_{65.5} \mathrm{Zr}_{34.5}\right)_{96} \mathrm{Al}_{4}$ alloy can be determined to be 0.58 and 0.389 from these measured temperatures, respectively. Although the values of $T_{\text {rg }}$ and $\gamma$ are still not much improved compared with those of the binary $\mathrm{Ni}-\mathrm{Zr}$ alloys, the $\left(\mathrm{Ni}_{65.5} \mathrm{Zr}_{34.5}\right)_{96} \mathrm{Al}_{4}$ alloy shows a larger supercooled liquid region of $49 \mathrm{~K}$. This means that the influence of the stability of the supercooled liquid on the GFA might be larger than $T_{\text {rg }}$ and $\gamma$ in the present $\mathrm{Ni}-\mathrm{Zr}-(\mathrm{Al})$ alloys.

\section{Conclusions}

The fully glassy sample in a bulk form cannot be obtained in the Ni-Zr alloys over a wide composition range, though they have $T_{g} / T_{l}$ and $\gamma$ values close or even higher than those of the binary $\mathrm{Cu}-\mathrm{Zr}$ BMGs studied earlier. The low stability of the supercooled liquid against crystallization and the formation of crystalline phases with large nucleation and growth rate of $\mathrm{Ni}$-Zr alloys have led to their low GFAs compared with those of the $\mathrm{Cu}-\mathrm{Zr}$ counterparts. Otherwise, their considerably lower thermal conductivities compared with $\mathrm{Cu}-\mathrm{Zr}$ alloys are also responsible for their low GFAs. The minor addition of $\mathrm{Al}$ can improve the GFAs of binary Ni-Zr alloys. The GFA of the binary $\mathrm{Ni}_{65.5} \mathrm{Zr}_{34.5}$ alloy alloyed with 4 or 5 at.\% $\mathrm{Al}$ was enhanced and a fully glassy rod with a diameter of $0.5 \mathrm{~mm}$ was formed.

\section{Acknowledgment}

The work was supported by the Open Project Program of Shenzhen Key Laboratory of Special Functional Materials of China (Grant no. T0907).

\section{References}

[1] A. Inoue, "Stabilization of metallic supercooled liquid and bulk amorphous alloys," Acta Materialia, vol. 48, no. 1, pp. 279-306, 2000.

[2] W. H. Wang, C. Dong, and C. H. Shek, "Bulk metallic glasses," Materials Science and Engineering R, vol. 44, pp. 45-89, 2004.

[3] H. S. Chen, "Thermodynamic considerations on the formation and stability of metallic glasses," Acta Metallurgica, vol. 22, no. 12, pp. 1505-1511, 1974.

[4] A. J. Drehman, A. L. Greer, and D. Turnbull, "Bulk formation of a metallic glass: $\mathrm{Pd}_{40} \mathrm{Ni}_{40} \mathrm{P}_{20}$," Applied Physics Letters, vol. 41, no. 8, pp. 716-717, 1982.

[5] A. Inoue, T. Zhang, and T. Masumoto, "Al-La-Ni amorphous alloys with a wide supercooled liquid region," Materials Transactions, vol. 30, pp. 965-972, 1989.

[6] A. Inoue, N. Nishiyama, and T. Masumoto, "Mg-Cu-Y bulk amorphous alloys with high tensile strength produced by a high-pressure die casting method," Materials Transactions, vol. 33, no. 10, pp. 937-945, 1992.

[7] A. Inoue, "High strength bulk amorphous alloys with low critical cooling rates," Materials Transactions, vol. 36, no. 7, pp. 866-875, 1995.

[8] A. Perk and W. L. Johnson, "A highly processable metallic glass: $\mathrm{Zr}_{41.2} \mathrm{Ti}_{13.8} \mathrm{Cu}_{12.5} \mathrm{Ni}_{10.0} \mathrm{Be}_{22.5}$," Applied Physics Letters, vol. 63, p. 2342, 1993.

[9] T. Zhang, A. Inoue, and T. Masumoto, "Amorphous Zr-Al-TM $(\mathrm{TM}=\mathrm{Co}, \mathrm{Ni}, \mathrm{Cu})$ alloys with significant supercooled liquid region of over 100 K," Materials Transactions, vol. 32, pp. 10051010, 1991.

[10] W. L. Johnson, "Bulk glass-forming metallic alloys: science and technology," MRS Bulletin, vol. 24, no. 10, pp. 42-56, 1999.

[11] X. Wang, I. Yoshii, A. Inoue, Y. H. Kim, and I. B. Kim, "Bulk amorphous $\mathrm{Ni}_{75-x} \mathrm{Nb}_{5} \mathrm{M}_{x} \mathrm{P}_{20-y} \mathrm{~B}_{y}(\mathrm{M}=\mathrm{Cr}, \mathrm{Mo})$ alloys with large supercooling and high strength," Materials Transactions, vol. 40, no. 10, pp. 1130-1136, 1999. 
[12] S. Yi, T. G. Park, and D. H. Kim, "Ni-based bulk amorphous alloys in the Ni-Ti-Zr-(Si, Sn) system," Journal of Materials Research, vol. 15, no. 11, pp. 2425-2430, 2000.

[13] W. Zhang and A. Inoue, "Formation and mechanical properties of Ni-based Ni-Nb-Ti-Hf bulk glassy alloys," Scripta Materialia, vol. 48, no. 5, pp. 641-645, 2003.

[14] D. Xu, G. Duan, W. L. Johnson, and C. Garland, "Formation and properties of new Ni-based amorphous alloys with critical casting thickness up to $5 \mathrm{~mm}$," Acta Materialia, vol. 52, no. 12, pp. 3493-3497, 2004.

[15] A. Inoue, W. Zhang, and T. Zhang, "Thermal stability and mechanical strength of bulk glassy Ni-Nb-Ti-Zr alloys," Materials Transactions, vol. 43, pp. 1952-1956, 2002.

[16] Y. Q. Zeng, A. Inoue, N. Nishiyama, and M. W. Chen, "Nirich Ni-Pd-P bulk metallic glasses with significantly improved glass-forming ability and mechanical properties by Si addition,” Intermetallics, vol. 18, no. 9, pp. 1790-1793, 2010.

[17] A. L. Greer, "Metallic glasses," Science, vol. 267, no. 5206, pp. 1947-1953, 1995.

[18] A. Inoue, W. Zhang, T. Zhang, and K. Kurosaka, "High-strength $\mathrm{Cu}$-based bulk glassy alloys in $\mathrm{Cu}-\mathrm{Zr}$-Ti and $\mathrm{Cu}-\mathrm{Hf}-\mathrm{Ti}$ ternary systems," Acta Materialia, vol. 49, no. 14, pp. 2645-2652, 2001.

[19] D. Xu, B. Lohwongwatana, G. Duan, W. L. Johnson, and C. Garland, "Bulk metallic glass formation in binary $\mathrm{Cu}$-rich alloy series- $\mathrm{Cu}_{100-x} \mathrm{Zr}_{x}(x=34,36,38.2,40$ at.\%) and mechanical properties of bulk $\mathrm{Cu}_{64} \mathrm{Zr}_{36}$ glass," Acta Materialia, vol. 52, no. 9, pp. 2621-2624, 2004.

[20] D. Wang, Y. Li, B. B. Sun, M. L. Sui, K. Lu, and E. Ma, "Bulk metallic glass formation in the binary $\mathrm{Cu}-\mathrm{Zr}$ system," Applied Physics Letters, vol. 84, pp. 4029-20, 2004.

[21] M. B. Tang, D. Q. Zhao, M. X. Pan, and W. H. Wang, "Binary CuZr Bulk Metallic Glasses," Chinese Physics Letters, vol. 21, no. 5, p. 901, 2004.

[22] L. Xia, W. H. Li, S. S. Fang, B. C. Wei, and Y. D. Dong, "Binary Ni-Nb bulk metallic glasses," Journal of Applied Physics, vol. 99, no. 2, Article ID 026103, 3 pages, 2006.

[23] D. V. Louzguine-Luzgin, T. Shimada, and A. Inoue, "A study of glass-formation, formation of the supercooled liquid and devitrification behavior of Ni-based bulk glass-forming alloys," Materials Science and Engineering A, vol. 449-451, pp. 198-202, 2007.

[24] T. Abe, M. Shimono, M. Ode, and H. Onodera, "Estimation of the glass forming ability of the Ni-Zr and the $\mathrm{Cu}-\mathrm{Zr}$ alloys," Journal of Alloys and Compounds, vol. 434-435, pp. 152-155, 2007.

[25] T. Fukunaga and A. C. Hannon, "Voronoi analysis of the structure of $\mathrm{Cu}-\mathrm{Zr}$ and $\mathrm{Ni}-\mathrm{Zr}$ metallic glasses," Intermetallics, vol. 16, pp. 893-897, 2006.

[26] D. V. Louzguine-Luzgin, A. D. Setyawan, H. Kato, and A. Inoue, "Influence of thermal conductivity on the glass-forming ability of Ni-based and Cu-based alloys," Applied Physics Letters, vol. 88, no. 25, Article ID 251902, 2 pages, 2006. 

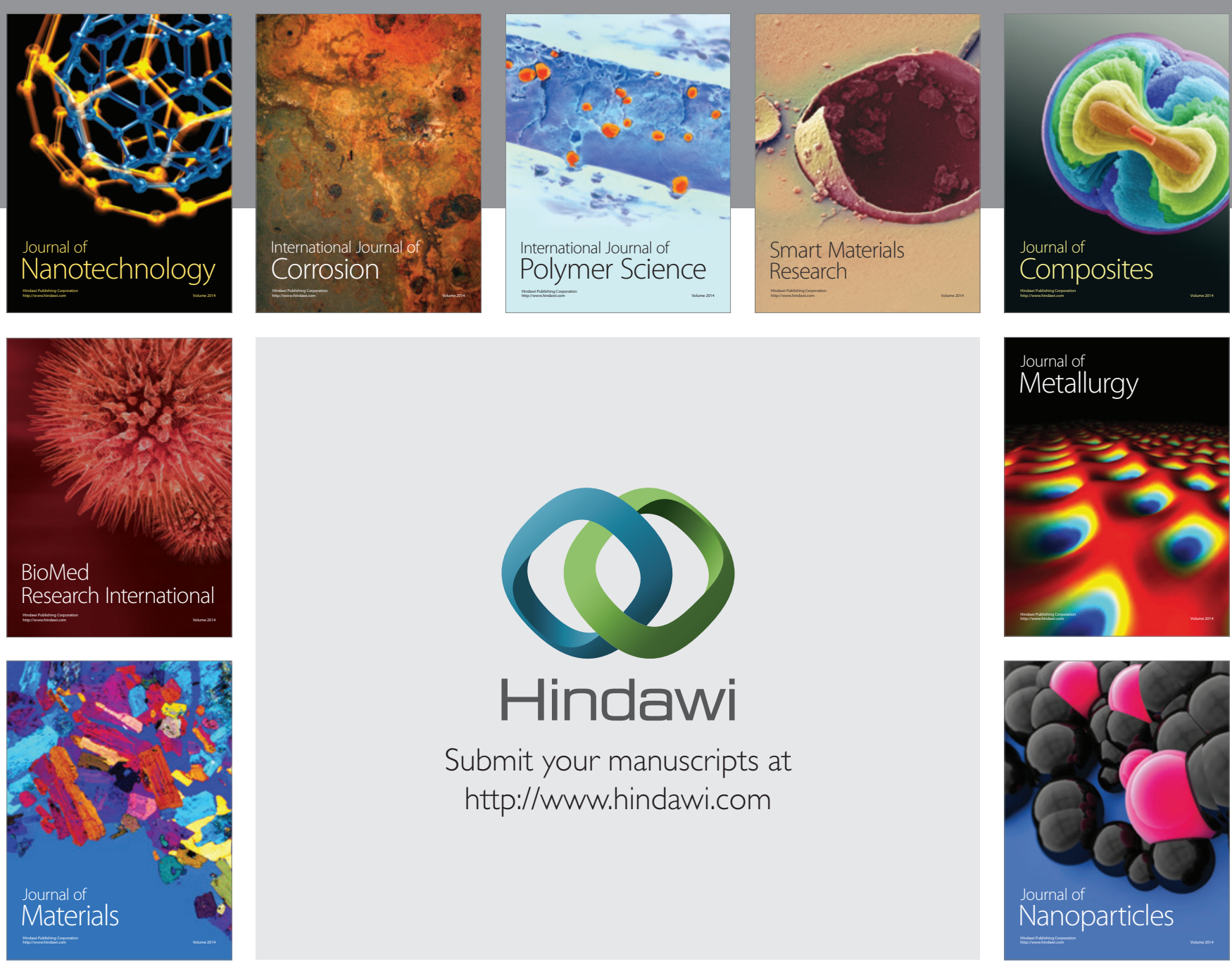

Submit your manuscripts at http://www.hindawi.com
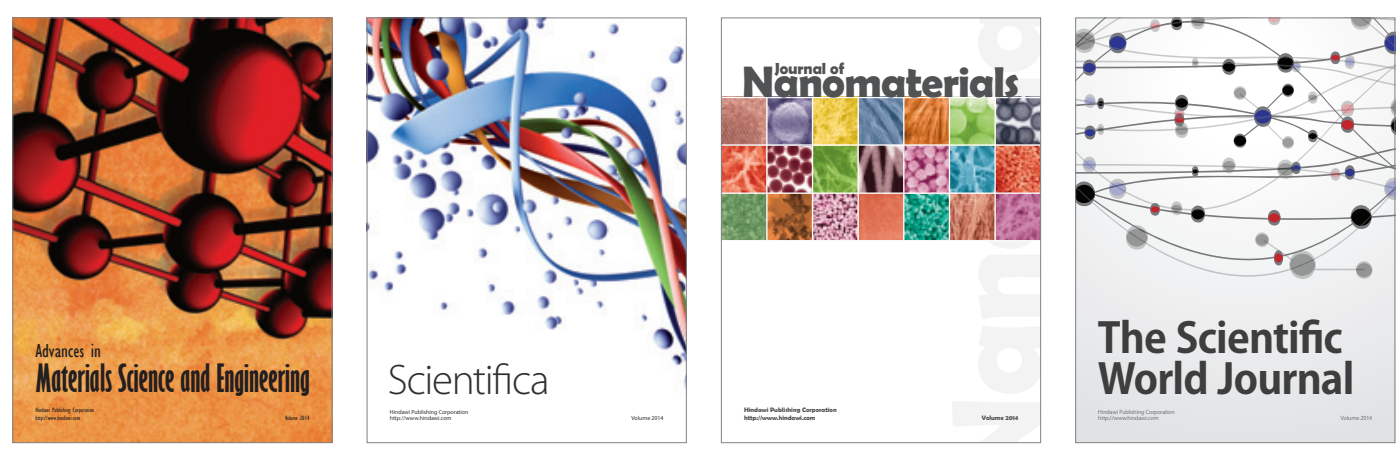

\section{The Scientific World Journal}
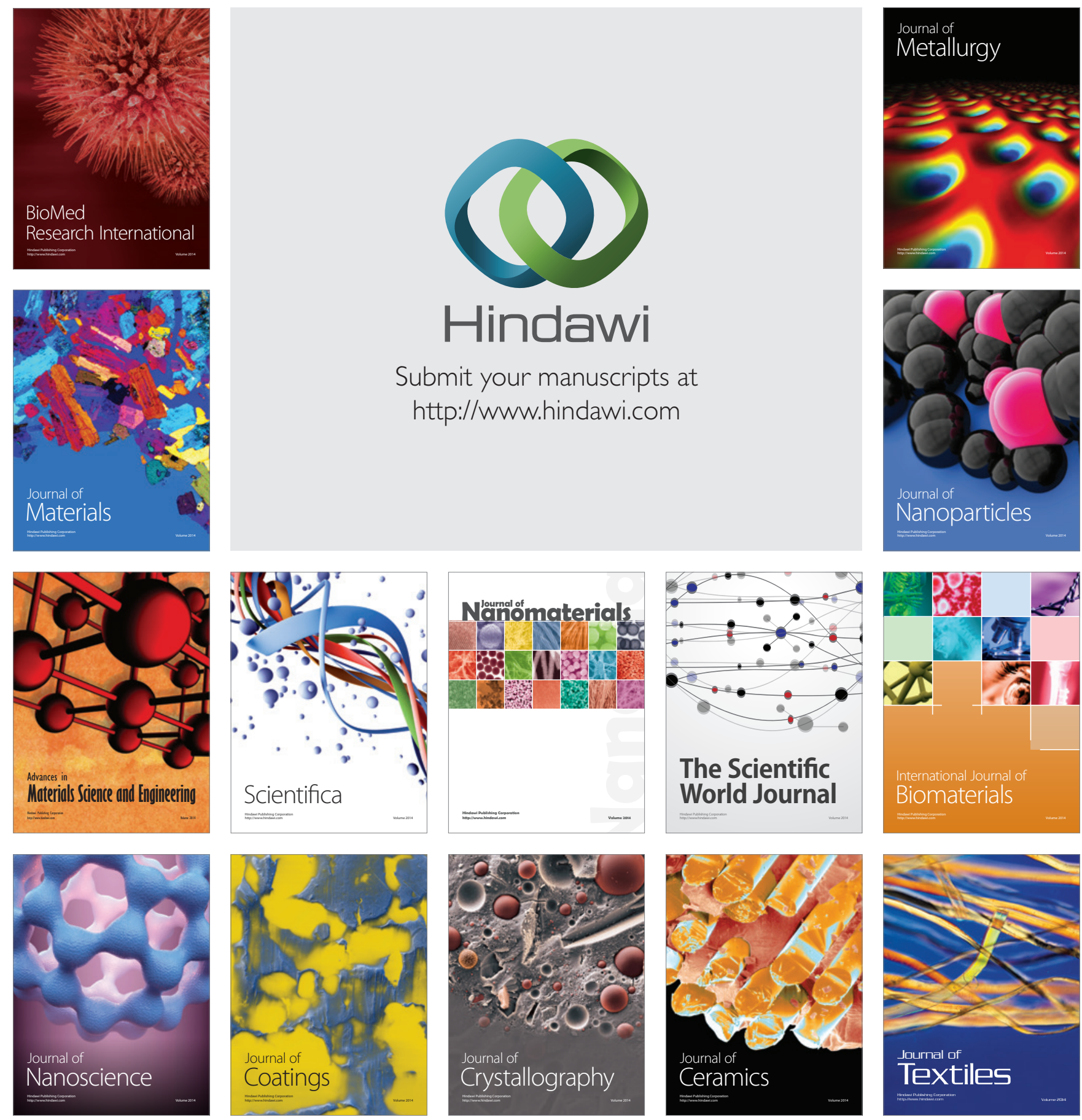